\author{
Łukasz Bojko* \\ ORCID: 0000-0001-9851-2757 \\ Uniwersytet Wrocławski
}

DOI: $10.19195 / 1733-5779.27 .6$

\title{
Między demoliberalizmem a państwem władczym. Wacława Makowskiego pochwała solidaryzmu i krytyka liberalizmu
}

\section{JEL Classification: K10}

Słowa kluczowe: Wacław Makowski, solidaryzm, Konstytucja Kwietniowa, sanacja

Keywords: Wacław Makowski, solidarism, April Constitution, sanation

\begin{abstract}
Abstrakt: Niniejszy artykuł zapoznaje czytelnika z poglądami prof. Wacława Makowskiego, wybitnego uczonego i znawcy prawa konstytucyjnego oraz karnego II RP, a także działacza obozu sanacji. Artykuł koncentruje się na krytyce liberalizmu i pochwale solidaryzmu. Zdaniem Wacława Makowskiego kryzys życia politycznego przedwojennej Polski wymagał zerwania z fundamentami konstytucji marcowej, przede wszystkim z liberalizmem politycznym i demokracją parlamentarną, które powinny zostać zastąpione ideą solidaryzmu będącego trzecią drogą pomiędzy autorytarnym jedynowładztwem a demokracją liberalną.
\end{abstract}

\section{Between demoliberalism and an imperious state: Wacław Makowski's praise of solidarism and criticism of liberalism}

Abstract: This article acquaints the reader with notions of Wacław Makowski, eminent professor of criminal and constitutional law and a sanation activist. The article particularly refers to his criticisms of liberalism and praise of solidarism. The constant crisis of the political life of the Second Polish Republic required an essential reform of political bases. According to Makowski one should break with the bases of the March Constitution, that is liberalism and parliamentary democratism in favour of solidarism, being an indirect form between authoritarian dictatorship and liberal democracy.

* Opiekun naukowy (Scientific Tutor) — Łukasz Machaj 


\section{Wstęp}

Przedmiotem niniejszego artykułu jest charakterystyka poglądów prof. Wacława Makowskiego na kwestię zmiany ustrojowej, która ma się dokonać na mocy uchwalenia nowej ustawy zasadniczej. Punktem wyjścia postulatu przebudowy życia państwowego było przekonanie Makowskiego, że wyczerpały się formy społeczne, intelektualne, polityczne i ustrojowe, które dominowały od drugiej połowy XIX wieku. Dynamika przeobrażeń zachodzących w ówczesnej międzywojennej rzeczywistości wymuszała, zdaniem Makowskiego, wypracowanie nowych reguł życia zbiorowego. Należało odejść do liberalizmu jako filozofii życia bazującej na egoistycznym indywidualizmie oraz zerwać z parlamentaryzmem, który w warunkach niskiej kultury politycznej rodzi partyjniactwo i zabija myślenie propaństwowe.

\section{Konstytucja Kwietniowa na tle ówczesnych przemian społeczno-politycznych}

Analizy naukowe piłsudczykowskiej Konstytucji Kwietniowej z 1935 roku koncentrują się głównie na kwestii wzmocnienia roli prezydenta i treści jego władzy lub na zagadnieniach natury politycznej, które dały impuls do wszczęcia prac nad zasadniczą reformą ustrojową Drugiej Rzeczypospolitej. W tym kontekście podkreśla się zwykle specyficzny klimat intelektualny lat trzydziestych ubiegłego wieku, a więc czas fascynacji rządami silnej ręki oraz panujący wówczas głęboki kryzys demokracji parlamentarnych na całym kontynencie europejskim. Rosnąca popularność prądów intelektualnych i politycznych, jeśli nie negujących, to na pewno podważających dziedzictwo rewolucji francuskiej, nie ominęła również Polski, co wydaje się naturalne i oczywiste ze względu na to, że u steru państwa było ugrupowanie, które przejęło władzę w sposób nielegalny i niedemokratyczny. Jak pisał A. Ajnenkiel, istota zachodzących przemian ustrojowo-politycznych w okresie międzywojennym była podobna pod względem jakościowym. Państwa ograniczały swobody obywatelskie oraz obniżały prawne i faktyczne znaczenie ciał przedstawicielskich na rzecz organów kierowniczych, a właściwie na rzecz jednoosobowej władzy arbitralnej, w praktyce nieponoszącej jakiejkolwiek odpowiedzialności przed żadnym organem państwowym. Różny był tylko zakres kompetencji naczelnego ośrodka decyzyjnego, jak również stopień ograniczenia swobód życia politycznego, w końcu inna była skala prześladowań własnych obywateli i opozycji. Innymi słowy, zasadnicza tendencja była ta sama, natomiast różnica leżała w skali lub zakresie zjawiska ${ }^{1}$.

Przedstawionej uwadze nie da się odmówić słuszności w tym sensie, że nie sposób zanegować fakt umacniania się tendencji antydemokratycznych, antyindy-

\footnotetext{
${ }^{1}$ Historia państwa i prawa Polski 1918-1939, cz. 1, red. F. Ryszka, Warszawa 1962, s. 150.
} 
widualistycznych, antyparlamentarnych itp. w większości ówczesnych państw europejskich, czy to w większym (na przykład Włochy, Niemcy), czy mniejszym (na przykład Polska, Litwa) stopniu. Wydaje się jednak, że wyrażona przez Ajnenkiela teza obarczona jest pewną wadą - mianowicie pomija ona aspekt doktrynalny, nie podkreśla różnic natury zasadniczej ani cech gatunkowych odróżniających systemy totalitarne od autorytarnych. Ujmując tę myśl inaczej, tezę Ajnenkiela można by skrócić do jednej otwartej kwestii: „Jeszcze autorytaryzm czy już totalitaryzm". W tej optyce totalitaryzm i demoliberalizm można by umiejscowić na dwóch przeciwległych końcach osi zjawisk ideowopolitycznych, a każde działanie odchodzące od demoliberalizmu można by interpretować w sensie przybliżonym, to jest nadawać mu charakter mniej lub bardziej totalitarny. Autorytaryzm jest zaś nie łagodniejszą formą totalitaryzmu, lecz osobnym zjawiskiem o właściwościach zasadniczo odmiennych od cech ustrojów totalitarnych. Zerwanie z fundamentalnymi zasadami demokratyzmu parlamentarnego może być czynione z rozmaitych pobudek i niekoniecznie musi oznaczać zamiar budowy państwa totalnego w większym czy mniejszym zakresie. Jedną z takich pobudek może być dążenie do znalezienia formy pośredniej między nadmiernym indywidualizmem i totalną wspólnotowością w sensie ideowym oraz między liberalizmem a dyktaturą w znaczeniu ustrojowym. W mojej opinii tą „trzecią drogą” miał być solidaryzm, naczelny ideowy fundament Konstytucji Kwietniowej, którego wielkim zwolennikiem był wybitny prawnik oraz profesor prawa karnego i państwowego Wacław Makowski (1880-1942), obok W. Sławka i S. Cara postać mająca największy wpływ na kształt sanacyjnej ustawy zasadniczej. Makowski był jednym z najznakomitszych prawników II RP, czego dowodem było piastowanie przez niego funkcji dziekana Wydziału Prawa Uniwersytetu Warszawskiego w latach 1935-1937, a także współautorstwo słynnego „Kodeksu Makarewicza” czy kodeksu karnego z 1932 roku.

Myśl Makowskiego, działacza Bezpartyjnego Bloku Współpracy z Rządem (BBWR) i przewodniczącego komisji konstytucyjnej sejmu — moim zdaniem najtrafniej oddaje ducha konstytucji z 1935 roku, toteż celem niniejszego artykułu jest przybliżenie jej czytelnikowi. Nie jest natomiast moim zamiarem analiza ani działalności politycznej obozu pomajowego po 1935 roku, ani przepisów konstytucji, regulujących uprawnienia poszczególnych władz (zwłaszcza nadrzędności prezydenta), bo zagadnienia te mają wystarczająco bogatą literaturę, choć nie sposób omówić ideę solidaryzmu, pomijając przy tym naczelne zasady ustrojowe zawarte w pierwszych dziesięciu artykułach Konstytucji Kwietniowej.

\section{Krytyka demokratyzmu i parlamentaryzmu}

Makowski swe rozważania o zmianie konstytucji podejmował z pozycji realizmu. Obserwacja zmian zachodzących w ówczesnym świecie doprowadziła go 
do przekonania, że wyczerpały się formy ustrojowe, które sprawdzały się jeszcze w drugiej połowie XIX wieku. Kryzys parlamentaryzmu w Polsce umieszczał on na szerszym tle przemian polityczno-społecznych całej Europy. Słabość demokracji parlamentarnych była zatem nie tylko cechą polskiego życia państwowego, ale powszechnym zjawiskiem występującym na całym kontynencie europejskim. Ustroje państwowo-polityczne znajdowały się na etapie zasadniczych przeobrażeń, co prowadziło do powstawania zupełnie nowych form stosunków społecznych i politycznych ${ }^{2}$. Śledzony przez Makowskiego proces ewolucji ustrojowej wymuszał jego zdaniem odejście od liberalnej konstrukcji państwa. W epoce dominacji solidarności grupowej, klasowej czy narodowej wyczerpała się formuła liberalna. Państwo nie mogło być dłużej zrzeszeniem poszczególnych jednostek, ale musiało przeistoczyć się w państwo solidarne, wspólnotowe. Wymagało to jednak zerwania z pierwotnym liberalizmem indywidualistycznym, gdyż tworzy on państwo na zasadzie ujmowanego cywilistycznie stosunku równorzędnych stron. Państwo zaś nie mogło być dłużej wyrazem kompromisu społecznego, lecz musiało stać się czynnikiem zwierzchnim nad całym społeczeństwem. Nie miała zatem dłuższej racji bytu indyferentna ideowo liberalna demokracja parlamentarna.

W przekonaniu Makowskiego należało zerwać z dziewiętnastowiecznym ideałem państwa jako stróża praw jednostki, państwa liberalno-indywidualistycznego, którego rola została sprowadzona do minimum, to jest do stanowienia i egzekwowania prawa oraz do zapewnienia bezpieczeństwa wewnętrznego i zewnętrznego. Tak skonstruowane państwo, przyjmujące za naczelną zasadę nieingerowanie w życie jednostek, hołduje przesadnemu indywidualizmowi, który doprowadził do chaosu i anarchii, korzyści zaś z takiego stanu rzeczy odnosili jedynie silni i bogaci. Dlatego państwo, z konieczności, wbrew zasadom, na jakich się oparło, zostało zmuszone do odgrywania roli regulatora i pośrednika w stosunkach między ludźmi, często przy tym gwałcąc święte i nienaruszalne dla liberałów zasady: prawo do własności, swobody zawierania umów itp. Na aktualności straciły więc gwarancje negatywne praw jednostki, będące założeniem osiemnastowiecznego liberalizmu politycznego. W tej optyce prawa jednostki są postrzegane jako tarcza do obrony przed ingerencją zbiorowości czy też jednostki. Tymczasem to państwo jako organizacja społeczna jest źródłem praw jednostki, wobec czego należy zerwać z tezą o wzajemnym przeciwstawianiu sobie jednostki i państwa, a przyjąć koordynację pracy jako nowy fundament ustrojowo-ideowy. Ówczesne życie społeczne, jak dowodził Makowski, potrzebowało przede wszystkim gwarancji pozytywnych. Państwo nie mogło być już formą współżycia mającą na celu ochronę praw podmiotowych jednostki, lecz miało przeistoczyć się w organizację zbiorową dającą gwarancje rozwoju twórczości jednostki, gdyż naturalna ludzka

2 Mowa posła profesora Wacława Makowskiego, wygłoszona na posiedzeniu Sejmu dnia 3 marca 1931 roku na rozpoczęcie dyskusji konstytucyjnej. W. Makowski, Nowe Państwo. Pismo poświęcone zagadnieniom życia państwowego i międzynarodowego, Warszawa 1931, AAN 92/k. 49. 
zdolność do tworzenia zorganizowanych zbiorowości oraz łączenia ludzi różnych dążeń i interesów jest motywowana solidarnością w realizacji wspólnego dobra, a nie tylko obawą przed zagrożeniem czy dla podjęciem walki ${ }^{3}$.

Makowskiego krytyka liberalizmu wydaje się mieć wymiar wręcz ontologiczny, gdyż negował on od podstaw skonstruowaną przez liberałów koncepcję umowy społecznej. Przysługujące jednostce prawa i wolności są bowiem nie pierwotne i nadpaństwowe, lecz wtórne i podrzędne względem pierwotnego faktu społecznego, jakim jest zespolenie ludzi w całość organizacyjną. Pierwotna jest współpraca ludzi, a dopiero z niej wynikają prawa jednostkowe, nie zaś odwrotnie. W tym ujęciu prawa podmiotowe nie są postrzegane liberalnie jako wartość samoistna i absolutna, lecz widziane instrumentalnie jako narzędzie budowy życia społecznego i zbiorowego. Te podstawy solidaryzmu społecznego upowszechnił już wcześniej L. Duguit (zm. 1928), francuski prawnik oraz teoretyk państwa i prawa. Przekonywał on, że u podstaw życia zbiorowego leży pewna obiektywna, naczelna, naturalna i niepisana norma społeczna, nakazująca wszystkim ludziom przestrzeganie zasad solidarności i współdziałania, prawo zaś jest narzędziem, za pomocą którego państwo odkrywa, zabezpiecza i realizuje te zasady. Uprawnienia jednostki nie mają więc samodzielnego charakteru, lecz wynikają z ich funkcji społecznych ${ }^{4}$. Teoria ta korespondowała z poglądami Makowskiego, który uważał, że jednostki i zbiorowości są dla swego istnienia niezbędne, zatem „czas najwyższy by prawo stało się nie tylko aktem formalnie obowiązującym, ale merytorycznie słusznym, zgodnym z realizacją dobra wspólnego"5.

Liberalizm zakłada niejako sprzeczność celów i dążeń jednostki oraz państwa - mianowicie państwo ma tendencję do podporządkowywania sobie jednostek, zaś jednostki wykazują chęć przeciwstawiania się państwu. To założenie prowadzi liberałów do słusznego zresztą przekonania, że w starciu z organizmem zbiorowym, jakim jest państwo, jednostki z góry znajdują się na słabszej pozycji, dlatego też jednostkę należy wyposażyć w jak największą liczbę praw i swobód, zaś państwu możliwie jak najbardziej ograniczyć prawo do ingerowania w życie jednostki ${ }^{6}$. Liberalizm dąży więc do jak największego ograniczenia roli państwa. W tym ujęciu wolna od ingerencji państwa działalność jednostek nadaje pojęciu społeczeństwa charakteru samodzielnego względem państwa ${ }^{7}$. Konstytucja Kwietniowa to założenie odrzucała i stała na gruncie identyczności celów państwa i jednostek, co znalazło swoje odzwierciedlenie w jej art. 4 ust. 1: „W ramach Państwa i w oparciu o nie kształtuje się życie społeczeństwa” i art. 9: „Państwo

3 W.T. Kulesza, Wacław Makowski o państwie społecznym, Warszawa 1998, s. 71-113.

${ }^{4}$ W. Komarnicki, Ustrój państwowy Polski współczesnej. Geneza i system, Kraków 2006, s. 185.

${ }^{5}$ K. Grzybowski, Zasady konstytucji kwietniowej. Komentarz prawny do części I ustawy konstytucyjnej, Kraków 1937, s. 21.

6 Ibidem, s. 22.

7 W. Makowski, Nauka o państwie. Część pierwsza: teoria państwa, Warszawa 2014, s. 109. 
dąży do zespolenia wszystkich obywateli w harmonijnym współdziałaniu na rzecz dobra wspólnego" 8 . Państwo to dobro zbiorowe o charakterze ponadindywidualnym, podporządkowujące sobie interesy jednostkowe, ale jednocześnie jego istnienie zależy od aktywności jednostki, której twórczość jest „dźwignią życia zbiorowego" (art. 5 ust. 1) . $^{9}$ Makowski przekonywał, że dobro to nie tylko osobiste korzyści, czyli takie, które każdy obywatel indywidualnie osiąga dla siebie z powodu przynależności do państwa, lecz jest to przede wszystkim „dzieło zbiorowe”, a więc suma wszystkich działań obywateli, składająca się na dobro wspólne, czy, jak określał to Makowski, ,produkt powszechnej obywatelskości”. Dobro wspólne, jak pisał K. Grzybowski, było kryterium uzasadniającym prawo państwa do ingerencji w życie społeczeństwa. Gdy zatem zachodziła kolizja między interesem jednostki a interesem państwa, to państwo miało ograniczyć interes jednostki, kierując się dobrem wspólnym. Od uznania państwa zależał zakres wolności jednostki, bo jej granicą był interes ogółu. Dobro wspólne miało więc charakter naczelnej klauzuli generalnej nowego ustroju ${ }^{10}$.

\section{Makowskiego koncepcja identyczności państwa i społeczeństwa}

Z przytoczonych artykułów można wyprowadzić podzielaną przez Makowskiego tezę o ujmowaniu państwa i społeczeństwa jako dwóch tożsamych z sobą, a nie odrębnych, porządków życia zbiorowego. Państwo wpływa na kształt społeczeństwa i wyznacza mu kierunki rozwoju. Życie społeczne jest częścią życia państwowego z tą różnicą, że o ile funkcjonowanie państwa jest regulowane normami prawa pisanego, o tyle społeczeństwem rządzą niepisane normy społeczne, które powinny zostać ujęte w prawną formę naczelnych zasad ustrojowych o funkcji wychowawczej, a więc odwołujących się do powinności i poczucia obowiązku. W państwie, stawiającym na integrację z obywatelem, zasady te musiały przybrać postać deklaracji ideowych i państwowo-wychowawczych, gdyż poza swoim formalnoprawnym znaczeniem musiały odnosić się do materialnego życia zbiorowego i wskazywać mu kierunku rozwoju ${ }^{11}$. Rola tych dyrektyw ogólnych o charakterze ideologicznym była istotna tym bardziej, że stanowiły one wykładnię norm prawnych: im mniej sprecyzowaną treść miała dana norma, tym rosło znaczenie tych dyrektyw. Naczelnym celem twórców nowej ustawy zasadniczej było wytworzenie więzi moralnej między państwem a obywatelem, nie zaś przebudowa organizmu państwowego w ten sposób, by mechanicznie odwoływał się on do przymusu, aby egzekwować aktywność obywatela. Przekonywano, że

${ }^{8}$ Ustawa Konstytucyjna z dnia 23 kwietnia 1935 roku, Dz.U. z 1935 r. Nr 30, poz. 227.

9 W.T. Kulesza, Koncepcje ideowo-polityczne obozu rzadzacego w Polsce w latach 19261935, Wrocław-Warszawa-Kraków 1985, s. 177-178.

10 K. Grzybowski, op. cit., s. 23-40.

11 Ibidem, s. 5. 
silne i sprawne państwo można budować jedynie na trwałych podstawach moralnych i etycznych, zaś siła nigdy nie jest i nie będzie czynnikiem zespalającym jednostkę z państwem, wręcz przeciwnie — siła rodzi jedynie opór i wrogość jednostki wobec systemu, poza tym zbyt angażuje energię samego państwa, podczas gdy energię tę powinno ono czerpać od swych obywateli. Dążono więc do ukształtowania w jednostce poczucia odpowiedzialności za losy jej państwa, wychowania jej w duchu troski o dobro wspólne ${ }^{12}$.

Zespolenie jednostki z państwem w naturalny sposób pociągało za sobą konieczność rewizji znaczenia pojęcia wierności obywatelskiej. W demokracji liberalnej wierność ma charakter minimalistyczny i jest rozumiana jako nieczynienie nic wbrew państwu, niepodejmowanie prawnie sankcjonowanych działań uderzających w jego dobro i interesy. Demokracja solidarystyczna wypełnia to pojęcie nową treścią, wskutek czego nabiera ono znaczenia przede wszystkim pozytywnego i oznacza więź uczuciową i jedność emocjonalną z państwem i jego dobrem. Nie wystarczy zatem już minimum postawy propaństwowej wyrażającej się w prostym posłuszeństwie i przestrzeganiu prawa, lecz pierwszoplanowa staje się postawa maksymalistyczna, czyli aktywizacja jednostki we współdziałaniu z państwem dla dobra wspólnego ${ }^{13}$. S. Car, autor projektu Konstytucji Kwietniowej, stał na stanowisku, że istotą reformy ustrojowej było znalezienie formy pośredniej pomiędzy liberalizmem i parlamentaryzmem a dyktaturą ${ }^{14}$. Rozwój ustroju społecznego nie mógł iść dalej po linii zbyt przesadnej wolności jednostki, ale nie mógł iść też po linii omnipotencji państwa. Nowa formuła musiała łączyć kierowniczą rolę państwa w sprawach wspólnych najwyższej wagi z aktywnością jednostki ${ }^{15}$.

\section{Elitaryzm w ujęciu piłsudczyków}

W poglądach Makowskiego charakterystyczny był brak nadmiernego akcentowania prymatu państwa, co wyróżniało go na tle obozu sanacji, która z idei nadrzędności państwa uczyniła przecież swój naczelny fundament ideowo-polityczny. Makowskiemu zdecydowanie bliżej było do idei dobra wspólnego niż jakiejś cezarystycznej nadrzędności. Jednakże tylko pozornie prawdziwe jest twierdzenie, że idea dobra wspólnego, w oczywisty sposób mająca aktywizować jak najwięcej obywateli, stoi w sprzeczności ze społecznym elitaryzmem. Uznanie dla zasług na rzecz wspólnoty naturalnie prowadzi do różnicowania działań ludzkich i faworyzowania tych, którzy przez swoje oddanie sprawie dla dobra ogółu czynią

12 W. Komarnicki, op. cit., s. 156-158.

13 K. Grzybowski, op. cit., s. 54.

14 A. Ajnenkiel, Historia Sejmu Polskiego, t. 2, cz. 2. II Rzeczpospolita, Warszawa 1989, s. 183.

15 W. Kumaniecki, Nowa konstytucja polska, Kraków 1935, s. 83. 
najwięcej ${ }^{16}$. Oznaczało to nadanie elitaryzmowi charakteru bardziej moralnego niż politycznego, co stanowiło odejście od wzorców wielu ówczesnych państw europejskich, w których elitaryzm łączono przede wszystkim z określonym ruchem politycznym ${ }^{17}$. Błędem byłoby jednak przypuszczać, że wykazywane przez sanację tendencje elitarystyczne miały swoje źródło jedynie w wierze w abstrakcyjną siłę społeczną. Już bowiem na długo przed zamachem majowym środowisko piłsudczyków było przeświadczone o własnej misji. Jak trafnie pisał R. Wapiński, to oni zdobyli się na osamotnioną walkę zbrojną z zaborcami i to im — w ich przekonaniu - historia przyznała rację, gdyż naturalną konsekwencją podjętych przez nich działań zbrojnych było odzyskanie przez Polskę niepodległości. Świadomość roli historycznej, jaką odegrali, prowadziła ich do przekonania, że to oni są moralną i polityczną elitą państwa polskiego, która ma oddziaływać na społeczeństwo w sposób wychowawczy, by uczynić z niego partnera równorzędnego i współodpowiedzialnego za losy państwa ${ }^{18}$.

Elitaryzm, w rozumieniu sanacyjnym, nie oznaczał zerwania z zasadą równości, lecz wskazywał, że poza zabezpieczaną przez państwo równością formalnoprawną, oznaczającą uchylenie jakichkolwiek osobistych przywilejów i ograniczeń względem prawa stanowionego, istnieje jeszcze nierówność materialna, wyrażająca się w, jak to ujął Car, „bezinteresownej, nie cofającej się przed żadnym wysiłkiem zasłudze"19. Konsekwencją tego elitarystycznego spojrzenia był zamiar stworzenia obywatela nowego typu, głęboko identyfikującego się z państwem i jego dobrem. Dążenie to miało się urzeczywistnić w wymiarze instytucjonalnym. Najbardziej zasłużeni obywatele mieli uzyskać znaczący wpływ na losy państwa, ciesząc się specjalnym statusem politycznym, co zostało przedstawione na forum sejmowym w styczniu 1934 roku $^{20}$. Planowano wtedy utworzenie Kadry Obywatelskiej (zmienionej później na Legion Zasłużonych), mającej w przyszłości zastąpić instytucję senatu. Ten autorski pomysł Sławka został ostatecznie odrzucony przez Piłsudskiego, który koncepcję tę uznał za zbyt abstrakcyjną ${ }^{21}$. Niemniej zachował się art. 7 ust. 1 Konstytucji Kwietniowej, stanowiący „Wartością wysiłku i zasług obywatela na rzecz dobra powszechnego mierzone będą jego uprawnienia do wpływania na sprawy publiczne"22. U podstaw elitaryzmu

16 Jak stwierdził Car: „W państwie powinna panować rozumnie pojmowana wolność i równość, a jednocześnie dążenie do faworyzowania zasług dla dobra zbiorowego”. A. Ajnenkiel, op. cit., s. 183.

17 Ibidem, s. 28, 105.

18 R. Wapiński, Świadomość polityczna w Drugiej Rzeczypospolitej, Łódź 1989, s. 324-125.

19 W. Kumaniecki, op. cit., s. 106.

20 K. Kawalec, Spadkobiercy niepokornych. Dzieje polskiej myśli politycznej 1918-1939, Wrocław 2000, s. 192.

21 R. Wapiński, Historia polskiej myśli politycznej XIX i XX wieku, Gdańsk 1997, s. 209-210.

22 K. Grzybowski, Zasady konstytucji kwietniowej. Komentarz prawny do części I ustawy konstytucyjnej, Kraków 1937, s. 55. 
piłsudczyków leżał pogląd, że tylko elita jest zdolna do rozumienia polskiej racji stanu, dlatego też należy przebudować ustrój państwowy tak, aby zapewnić jej należytą pozycję, gdyż w warunkach stworzonych na mocy Konstytucji Marcowej, liczebnie niewielka elita nie mogła zdobyć odpowiedniej przewagi w organach przedstawicielskich ${ }^{23}$.

Dla Makowskiego mitem był liberalny aksjomat człowieka jako istoty przedspołecznej, podmiotu przyrodzonych praw. Obserwowany przez niego proces przeobrażeń ustrojowo-politycznych doprowadził go do przekonania, że „,człowiek jest zmęczony indywidualizmem, zbyt słaby aby wystarczyć sobie sam"24. Człowiek nie jest jedynie odrębnym podmiotem, lecz jest także twórczym czynnikiem zbiorowości. Zwrócenie się w kierunku państwa solidarystycznego wymagało jednak przebudowy życia politycznego, które nadałoby nowe znaczenie relacji jednostka-zbiorowość. Należało zatem odejść od państwa liberalnego możliwie jak najbardziej wycofanego z życia społecznego na rzecz państwa pośredniczącego w konfliktach między różnymi grupami społecznymi. Makowski odrzucał państwo rozumiane jako sui generis umowę polityczną zawartą w celu zachowania praw jednostki. Zamiast tego wysunął koncepcję państwa jako naturalnego, opartego na solidarności zespolenia obywatelskiego, powstałego dla zaspokajania potrzeb życia zbiorowego. Zamysł ten oczywiście stał w rażącej sprzeczności z porządkiem ustrojowym stworzonym na mocy Konstytucji Marcowej, toteż za konieczne uznawał Makowski jej zmianę. Konstytucji z 1921 roku wytykał oparcie na indywidualizmie i wzajemnym przeciwstawianiu sobie „człowieka człowiekowi i państwu, państwu człowiekowi i jego organizacjom”, tymczasem zasadą naczelną powinno być solidarne współdziałanie jednostki i zbiorowości ${ }^{25}$.

Choć na wstępie zaznaczyłem, że nie będę skupiać się na działalności piłsudczyków po 1935 roku, gdyż nie dotyczy ona myśli Makowskiego, a zatem wykracza poza ramy tematyczne niniejszego artykułu, na zakończenie jednak chciałbym poczynić jedną uwagę natury polemicznej wobec tezy, że Konstytucja Kwietniowa, niezależnie od szlachetnych intencji jej twórców, w tym więc Makowskiego, zalegalizowała rządy autorytarne. Otóż późniejszy autorytaryzm spod znaku Ozonu, o zabarwieniu zresztą mocno nacjonalistycznym, nie był ugruntowany w porządku konstytucyjnym, lecz wynikał z czynników faktycznych. Innymi słowy, w mojej opinii nie można mówić, iż rzeczywistość polityczna po 1935 roku była efektem realizacji zapisów nowej ustawy zasadniczej. Propaganda sanacji lubiła podkreślać, że Konstytucja Kwietniowa jako ostatni akt prawny podpisany przez Piłsudskiego przed śmiercią, stanowiła jego polityczny testament. Nie jest to prawdą, jako że umierający Marszałek nie tylko nie zapoznał się z jej treścią, ale nawet

23 A. Garlicki, Od Brześcia do maja, Warszawa 1986, s. 267.

24 G. Ławnikowicz, Między koniecznościa państwa a pochwała autorytaryzmu. Koncepcje państwa społecznego Wacława Makowskiego, Lublin 2014, s. 153, 188.

25 W.T. Kulesza, Wactaw Makowski..., s. 88-199. 
nie przeczytał jej naczelnych tez ustrojowych ${ }^{26}$. O ile więc na użytek zewnętrzny można było posługiwać się ,argumentem testamentu”, o tyle brak przywiązania czy wręcz zainteresowania Piłsudskiego nową ustawą zasadniczą sprawiał, że przywódcy sanacyjni bez oporów zaczęli odchodzić od jej ducha i litery już latem roku jej uchwalenia ${ }^{27}$. Konstytucja Kwietniowa pozostała więc właściwie prawem martwym, aktem „pozostawionym w próżni” i niewywierającym wpływu na stosunki faktyczne kształtowane przez marszałka E. Rydza-Śmigłego i jego otoczenie. Innymi słowy, historia nie dała szansy ani Konstytucji Kwietniowej, ani zawartej w niej myśli Makowskiego.

\section{Podsumowanie}

Makowski przejawiał, konstytuujące zresztą obóz pomajowy, głębokie rozczarowanie demokracją parlamentarną. Praktyka lat 1919-1926 dowiodła, że recepcja zewnętrznych, głównie francuskich wzorców na grunt polski się nie sprawdziła. Wydawało się, że sposobem na związanie obywatela z państwem było zaprowadzenie demokracji parlamentarnej i ten ustrojowy model będzie stanowić panaceum na wszystkie niedoskonałości odrodzonej Rzeczypospolitej. Troskę o losy państwa polscy obywatele mieli w akcie wyboru przenieść na swoich przedstawicieli, tym samym niejako pozbawiając się odpowiedzialności za sprawy ojczyzny. Życie jednakże ukazało, iż elity polityczne nie dorosły do roli, jaka została im powierzona. Przyczyną słabości życia państwowego II RP był brak wykształconej kultury demokratycznej i niedojrzałość polityczna, ostre walki partyjne, podatność społeczeństwa na demagogię itp. Skutkami zaś patologiczne zjawiska: korupcja, nepotyzm, prywata, partyjniactwo. Kryzys parlamentaryzmu w Polsce nakładał się na pogarszającą się w latach trzydziestych sytuację międzynarodową, rosnące zagrożenie wojną. Nic zatem dziwnego, że polską odpowiedzią na wyzwania epoki była zasadnicza przebudowa ustroju państwowego. Makowski wskazywał, że cała ówczesna Europa podzieliła się na dwa zwalczające się obozy: $\mathrm{z}$ jednej strony ustawiający społeczeństwa w szeregi marszowe, zabijający wolność totalizm, z drugiej — przeciwstawiający państwu jednostkę egoistyczny liberalizm. Zadaniem Polski było, w przekonaniu Makowskiego, nie znalezienie się w żadnym z tych obozów, lecz realizacja koncepcji ustrojowej pośredniej, czyli pomiędzy państwem totalnym a liberalnym. Tą ideą miało być państwo solidarystyczne oparte na zjednoczeniu i współdziałaniu uświadomionych obywatelsko jednostek z państwem ${ }^{28}$.

26 A. Garlicki, op. cit., s. 279.

27 A. Chojnowski, Pitsudczycy u władzy. Dzieje Bezpartyjnego Bloku Wspótpracy z Rządem, Wrocław 1986, s. 222.

28 Ibidem, s. 203. 


\title{
Bibliografia
}

Ajnenkiel A., Historia Sejmu Polskiego, t 2, cz. 2. II Rzeczpospolita, Państwowe Wydawnictwo Naukowe, Warszawa 1989.

Chojnowski A., Pitsudczycy u władzy. Dzieje Bezpartyjnego Bloku Współpracy z Rządem, Wydawnictwo Zakładu Narodowego im. Ossolińskich, Wrocław 1986.

Garlicki A., Od Brześcia do maja, Spółdzielnia Wydawnicza Czytelnik, Warszawa 1986.

Garlicki A., Piękne lata trzydzieste, Prószyński i S-ka, Warszawa 2008.

Grzybowski K., Zasady konstytucji kwietniowej. Komentarz prawny do części I ustawy konstytucyjnej, Skład Główny G. Gebethner i Wolff, Kraków 1937.

Historia państwa i prawa Polski 1918-1939, cz. 1, red. F. Ryszka, Państwowe Wydawnictwo Naukowe, Warszawa 1962.

Kawalec K., Spadkobiercy niepokornych. Dzieje polskiej myśli politycznej 1918-1939, Wydawnictwo Zakładu Narodowego im. Ossolińskich, Wrocław 2000.

Komarnicki W., Ustrój państwowy Polski współczesnej. Geneza i system, Wydawnictwo Uniwersytetu Jagiellońskiego, Kraków 2006.

Kulesza W.T., Koncepcje ideowo-polityczne obozu rzadzacego w Polsce w latach 1926-1935, Wydawnictwo Zakładu Narodowego im. Ossolińskich, Wrocław-Warszawa-Kraków 1985.

Kulesza W.T., Wacław Makowski o państwie społecznym, Wydawnictwo Sejmowe, Warszawa 1998.

Kumaniecki W., Nowa konstytucja polska, nakładem autora, Kraków 1935.

Ławnikowicz G., Między koniecznościa państwa a pochwała autorytaryzmu. Koncepcje państwa społecznego Wacława Makowskiego, Wydawnictwo Uniwersytetu Marii Curie-Skłodowskiej, Lublin 2014.

Makowski W., Nauka o państwie. Część pierwsza: teoria państwa, Wydawnictwo Sejmowe, Warszawa 2014.

Makowski W., Nowe Państwo. Pismo poświęcone zagadnieniom życia państwowego i międzynarodowego, Księgarnia F. Hoesicka, Warszawa 1931.

Wapiński R., Historia polskiej myśli politycznej XIXi XX wieku, Wydawnictwo ARCHE, Gdańsk 1997.

Wapiński R., Świadomość polityczna w Drugiej Rzeczypospolitej, Wydawnictwo Łódzkie, Łódź 1989.

\section{Between demoliberalism and an imperious state: Wacław Makowski's praise of solidarism and criticism of liberalism}

\author{
Summary
}

As he was forming the camp of sanation, Makowski displayed deep disappointment with parliamentary democracy. Years of experience with parliamentary democracy convinced him that French standards had not worked correctly within the territory of the Second Polish Republic. It had seemed that the system of parliamentary democracy would eliminate all defects in the national life and would connect the citizen with the Polish state. Polish citizens were supposed to transfer their care about the fate of the state to their representatives through an act of choice, depriving themselves of the responsibility for issues of the homeland. However in practice the political elites had not lived up to the role which was entrusted to them. A lack of an educated democratic culture and a political immaturity caused the weakness of the national life of the Second Polish Republic, party fights, susceptibility of society to demagoguery, etc. The effects of this phenomenon were: corruption, nepotism, self-interest, petty party politics. The crisis of the parliamentary system in Poland overlapped with the international situation deteriorating in the $1930 \mathrm{~s}$, the growing threat of 
war. It was not strange that the Polish reply to the challenges of these times was a fundamental reconstruction of the national system. Makowski showed that the entire contemporary Europe had split into two camps fighting each other. On the one hand there was totalitarianism killing freedom, on the other egotistical liberalism. In the opinion of Makowski the Polish reason of state was to find a constitutional solution between totalitarianism and democratic liberalism. 